\title{
Omep Publications
}

France: Henri Wallon

Le 23 mai 1974 s'est tenue, dans la grande salle de l'UNESCO, sous le patronage de $M$. Fontante, ministre de l'éducation nationale, et de $M$. René Maheu, directeur général de l'UNESCO, une nouvelle "Journée internationale" de 1'OMEP à laquelle furent conviés les comités nationaux voisins de Belgique, Espagne, Italie et Suisse, représentés par leur présidente et leur secrétaire générale ainsi que les personnalités de 28 pays ayant qualité d'ambassadeurs, conseillers culturels, etc., délégués permanents de leurs pays respectifs à l'UNESCO.
Il s’agissait de célébrer Henri Wallon, grand savant et psychologue français (1879-1962).

Les exposés et conférences des orateurs ont été publiés par le comité français; cette brochure contient les conférences de MM. les professeurs Mialaret et Zazzo et les interventions de M. Limouzy, Secrétaire d'Etat, au nom du ministre de l'éducation nationale, de $M r$. Knapp, de l'UNESCO, au nom de M. René Maheu, et de notre présidente Mme HerbinièreLebert.

(Secrétariat du Comité français: 1 Rue Gustave Rouanet, 75018 Paris. Prix 5,00 Frs.)

The following is a summary of the above publication which commemorated International OMEP Day 23 May 1974 -(Editor's Note)

\section{Wallon and preschool educators (Gaston Mialaret)}

Henri Wallon is considered to be one of the greatest French psychologists. He introduced a programme of schools reform and created the first group of psychologists working in schools. Wallon sees the child as a total being; he examines the interplay of biology-sociology, pathology and psychology in accounting for each child's individuality. For Wallon, understanding the child means being able to influence him, and an understanding is to be sought in biology as much as in family relations. This study of all the influences exercised on the individual gives a new basis to education. The teacher of "ecole maternelle" keeps her affective contact with the child but tries to foresee and evaluate the effects of her actions on his personality.

The conditions in which the child is raised and develops must never be forgotten. The "milieu" is thus considered as having a pedagogic action. The chief aspects of Wallon's psychology (as related to the young child) are based on importance of education and psychomotricity.

Emotions are the first means of communication and are the first conditions of the appearance of intelligent acts. We must then remember that young children are not receptive to purely verbal relations, but also that we can not educate a child only through emotions. In the same way motor activities prepare future intellectual activities, but only if they have the pleasant feeling tone, characteristic of play. Observations of the gestures of the young child is also very important as gesture has an imitative and representative value and allows the child to structure his body and spatial representation. Emotion and psychomotricity merge in play and gesture.

These represent but a few aspects of the evolution of personality but they justify the link stressed in Wallon's title 'From Art to Thought' which means the passage from practical to conceptual inteiligence.

\section{Origins and actuality of Henri Wallon's thinking (Rene Zazzo)}

Wallon was first a lycee teacher of philosophy after which he studied medicine. It was these two strands of philosophy and neuropsychiatry plus psychology which informed his thinking and resulted in his fascination for ambiguity and even contradiction; the problem of organic vs. social; the individual vs. society; organic vs. psychological; body vs. soul. Rene Zazzo, who worked with Wallon for years and succeeded him as director of Child Psychological Laboratory, demonstrates the importance of both the social and biological aspects of human development.

For Wallon the first human relations are symbiotic, and the image of the other members of the dyad is imprinted in us. By observation of children he postulated the role of the tonic function and its impact on postures and emotions.

However, Wallon's role in psychology is not limited to the study of emotions and psychomotricity, and Zazzo, in a parallel between Wallon and Piaget, analyses the former's contribution to the development of thought and intelligence. Wallon died in 1962, but much of his research work continues today and the influence of his work can be seen at many points in child psychology. 